\title{
Cell-laden alginate hydrogels for the treatment of diabetes
}

Izeia, Lukin; da Silva, Tatiane Eufrásio; Dolatshahi-Pirouz, Alireza; Ostrovidov, Serge; Paolone, Giovanna; Peppas, Nicholas A.; De Vos, Paul; Emerich, Dwaine; Orive, Gorka

\section{Published in:}

Expert Opinion on Drug Delivery

Link to article, DOI:

$10.1080 / 17425247.2020 .1778667$

Publication date:

2020

Document Version

Peer reviewed version

Link back to DTU Orbit

Citation (APA):

Izeia, L., da Silva, T. E., Dolatshahi-Pirouz, A., Ostrovidov, S., Paolone, G., Peppas, N. A., De Vos, P., Emerich, D., \& Orive, G. (2020). Cell-laden alginate hydrogels for the treatment of diabetes. Expert Opinion on Drug Delivery, 17(8), 1113-1118. https://doi.org/10.1080/17425247.2020.1778667

\section{General rights}

Copyright and moral rights for the publications made accessible in the public portal are retained by the authors and/or other copyright owners and it is a condition of accessing publications that users recognise and abide by the legal requirements associated with these rights.

- Users may download and print one copy of any publication from the public portal for the purpose of private study or research.

- You may not further distribute the material or use it for any profit-making activity or commercial gain

- You may freely distribute the URL identifying the publication in the public portal 


\title{
Expert Opinion on Drug Delivery
}

\section{Cell-laden alginate hydrogels for the treatment of diabetes}

\author{
Lukin Izeia , Tatiane Eufrasio-da-Silva , Alireza Dolatshahi-Pirouz, Serge \\ Ostrovidov, Giovanna Paolone, Nicholas A. Peppas , Paul De Vos , Dwaine \\ Emerich \& Gorka Orive
}

To cite this article: Lukin Izeia , Tatiane Eufrasio-da-Silva , Alireza Dolatshahi-Pirouz, Serge Ostrovidov, Giovanna Paolone , Nicholas A. Peppas , Paul De Vos , Dwaine Emerich \& Gorka Orive (2020): Cell-laden alginate hydrogels for the treatment of diabetes, Expert Opinion on Drug Delivery, DOI: $10.1080 / 17425247.2020 .1778667$

To link to this article: https://doi.org/10.1080/17425247.2020.1778667

Accepted author version posted online: 09 Jun 2020.

Submit your article to this journal ๘

山 Article views: 19

à

View related articles $\sqsubset$

View Crossmark data $₫$ 
Publisher: Taylor \& Francis \& Informa UK Limited, trading as Taylor \& Francis Group

Journal: Expert Opinion on Drug Delivery

DOI: $10.1080 / 17425247.2020 .1778667$

\section{Cell-laden alginate hydrogels for the treatment of diabetes}

Lukin Izeia $^{1,2}$, Tatiane Eufrasio-da-Silva ${ }^{3}$, Alireza Dolatshahi-Pirouz ${ }^{3,4}$, Serge Ostrovidov ${ }^{5}$, Giovanna Paolone ${ }^{6}$, Nicholas A. Peppas ${ }^{7}$, Paul De Vos ${ }^{8}$, Dwaine Emerich $^{9}$, Gorka Orive ${ }^{1,2,10,11, *}$

1. NanoBioCel Group, Laboratory of Pharmaceutics, School of Pharmacy, University of the Basque Country UPV/EHU, Paseo de la Universidad 7, Vitoria-Gasteiz 01006, Spain

2. Biomedical Research Networking Centre in Bioengineering, Biomaterials and Nanomedicine (CIBER-BBN). Vitoria-Gasteiz, Spain

3. Radboud university medical center, Radboud Institute for Molecular Life Sciences, Department of Dentistry - Regenerative Biomaterials, Philips van Leydenlaan 25, 6525EX Nijmegen, The Netherlands

4. Department of Health Technology, Institute of Biotherapeutic Engineering and Drug Targeting, Center for Intestinal Absorption and Transport of Biopharmaceuticals Technical University of Denmark, Lyngby, 2800 Kgs, Denmark.

5. Center for Minimally Invasive Therapeutics (C-MIT) Department of Radiological Sciences. University of California. Los Angeles, CA 90095, USA

6. Department of Diagnostic and Public Health, Section of Pharmacology, University of Verona, Verona, Italy

7. Departments of Pharmaceutics, Chemical and Biomedical Engineering. 1 University Station, C-0400. The University of Texas at Austin. Austin, TX 787120231

8. University of Groningen, Pathology and Medical Biology Section, Immunoendocrinology, Groningen, The Netherlands

9. Gloriana Therapeutics, Inc. (formerly NsGene Inc.), Providence, Rhode Island, USA 
10. University Institute for Regenerative Medicine and Oral Implantology - UIRMI (UPV/EHU-Fundación Eduardo Anitua), Vitoria, Spain

11. Singapore Eye Research Institute, The Academia, 20 College Road, Discovery Tower, Singapore

${ }^{*}$ Correspondence

Gorka Orive

Email: gorka.orive@ehu.eus 


\begin{abstract}
Introduction: Diabetes mellitus is an ever-increasing medical condition that currently suffers 1 of 11 adults who may have lifelong commitment with insulin injections. Cell-laden hydrogels releasing insulin may provide the ultimate means of correcting diabetes. Here, we provide insights of this cell-based approach including latest preclinical and clinical progress both from academia and industry.
\end{abstract}

Area covered: The present article focuses on reviewing latest advances in cellladen hydrogels both from the technological and biological perspective. The most relevant clinical results including clinical trials are also discussed.

Expert opinion: Current progress in technological issues (stem cells, devices, biomaterials) have contributed cell encapsulation science to have an very relevant progress in the field of diabetes treatment.

Keywords: Diabetes mellitus, cell encapsulation, cell-laden hydrogels, alginate, drug delivery 


\section{Article highlights}

- $\quad$ Cell-laden hydrogels enable long-term release of biological active agents such as insulin.

- $\quad$ Biological, material and technological aspects are key to success.

- $\quad$ Some approaches are being evaluated in clinical trials (Phase 1-2)

- $\quad$ Adequate source of insulin producing cells remains a critical issue.

- $\quad$ Stem-cell technologies have raised optimism about the scalable generation of insulin producing cell sources

\section{Introduction}

Diabetes mellitus is a serious worldwide medical condition impacting quality of life and the health care system. According to the International Diabetes Federation, 463 million adults ( 1 of 11 ) were affected in 2019 and that number is expected to increase to 700 million by 2045. Furthermore, the incidence of type 1 diabetes (T1D) has increased $3-4 \%$ over the last 30 years which support the influence of environmental factors (1). Current total annual medical costs are enormous and may be as high as 760 billion dollars (2). In the case of type 1 diabetes (T1D), the National Diabetes Statistics Report has shown that it is increasing among people under 20 (3). In this type of diabetes, pancreatic $\beta$-cells are progressively lost, daily injections of insulin are associated with frequent hypoglycemia and threat for disabling hypoglycemic unawareness. Recent progress in the field has shown that a number of factors including $\beta$-cell gene expression, islet morphology and endoplasmic reticulum stress signaling have a critical role in $\beta$-cell failure in T1D (mostly IRE1 driven) and T2D (mostly PERK-elF2 $\alpha$ dependent) (4).

From a therapeutic perspective, automated insulin pumps equipped with sensors to monitor blood glucose and mimic the natural insulin release could address the current challenges in the field. However, accurate monitoring of glycemia during 
physical activity or at night can be difficult to achieve, which has prompted engineers to look for more accurate and more responsive systems (5).

Implantation of insulin-producing islet cells may provide the ultimate means of correcting T1D. The technology of cell-laden hydrogels is fairly simple, it consists on enclosing insulin-secreting within semipermeable hydrogels, usually implantable, and coated with a polymeric thin cover, which permits nutrient exchange and exchange of cell-produced biologically active agents in the absence of immunological rejection. This approach is now being explored in a wide range of human diseases including blood disorders, acute liver failure, spinal cord injury, and diabetes(5).

The technology, however, is not new. The leading concept dates to 1960, when T.M.S. Chang first proposed the idea of the "artificial cell" (6). Shortly thereafter, the therapeutic benefits of encapsulated pancreatic islets were demonstrated by Lim and Sun in diabetic rats and by Soon-Shiong in a diabetic patient (7). With those results, a few companies started developing devices for encapsulating pancreatic cells. Today, several industrial efforts remain underway including efforts by Seraxis, Pharmacyte, Semma Therapeutics, Sernova, and ViaCyte.

Currently, some of these approaches are being evaluated in clinical trials (Phase 12) (5), though none of them has moved forward into the clinics. "Good things take time" is apt proverb for this field but it is what has occurred during that time that leads many to the conclusion that we are on the brink of being able to at least finally test optimal (and hopefully prove) encapsulated islet-containing devices. This optimism is based largely on significant progress in the interface of biomaterials and cellular engineering. Many first encapsulation attempts were done without a global technogical/biological evaluation, optimized cell dose or non-suitable cell selection. Below we discuss, some of the pivotal advances and how they contribute to this optimism.

\section{Technological issues}

Several decades of research and clinical evaluations have uncovered the complexity of merging scientific fields as diverse as cell biology, engineering, biomaterials, and immunology to develop a therapeutic. The potential of cell encapsulation requires a partnership that takes advantage of the ingenuity of academia and the development experience of large pharma (8). As discussed in detail below, the manufacture of high-quality biocompatible material is available on reasonably large scales and in 
combination with equally scalable human stem cell-derived beta cells are significant advancements if not true breakthroughs (9).

From an industrial perspective, we are now more able to address 2 overarching obstacles that have plagued the field of cell encapsulation; identifying a potentially therapeutic factor and being able to deliver it in a pharmacokinetically appropriate manner (5). For diabetes, the first issue is straightforward as insulin is a known commodity. Insulin replacement works and pancreatic transplants can cure the disease. This stands in contrast to other indications where delivering potentially efficacious molecules such as trophic factors or antibodies (often using genetically modified cells that are unrelated to the disease itself) requires a different starting point with unknown variables centered around dosing, efficacy, and toxicity (10). With increasingly large-scale human stem cell-derived beta cell production it should be possible to focus increasingly on the second issue. Without reliable, consistent, and readily available cells it has not possible to establish manufacturing and quality controls that enable the evaluation of chemical and structural changes in the configuration of cell containing devices (5). Insulin administration has known pharmacokinetic and glucose responsiveness requirements. But in the past, limited supplies of cell preparations, and lab to lab variability has made animal to human translations difficult (8). Of course, further refinements in differentiation protocols will optimize cell identify/composition (beta and other islet cell types) purity (removing unwanted cells), and potency (insulin control and responsiveness) (11). Moreover, other technologies including cellular engineering approaches such as CRISPR may allow future cellular tweeking to minimize host responses to grafting or facilitate the response of the encapsulated cells to environmental cues (12).

\section{Device considerations}

The 3 major encapsulation approaches for islet are intravascular macrocapsules, extravascular macrocapsules and extravascular microcapsules (13-15) (Figure 1). Intravascular devices are connected to the vascular system of the patient allowing rapid exchange of glucose, insulin and nutrients (16) (Figure 1.c). Although potentially efficacious, clinical application is compromised by high risk of thrombosis and infection. Although some new approaches for intravascular devices are under investigation (17) most current efforts are focused on extravascular devices. Extravascular devices can be safely implanted in readily accessible implantation 
sites and can be retrieved/replaced if replenishable cell sources (stem or progenitor cells) are considered or if functional limitations such as poly-hormonal secretion, or excessive hormone secretion necessitate refilling $(18,19)$.

Extravascular devices are available in macro- and microcapsules. Within macrodevices groups of islets are encapsulated and implanted into surgically accessible sites such as under the skin or intraperitoneally. A challenge in the field of macrocapsules has been a non-ideal surface to volume ratio (8). As a consequence, diffusion of oxygen can be slow and islet-cells compete for these nutrients, limiting seeding density to $5-10 \%$ of the volume of the device (13). Novel developments to overcome these issues include oxygen generators such as the so-called Beta-O2 device which is a macrodevice connected to an oxygen port (20-22) (Figure 1.b). Another design are lipid membranes based on the cornea that facilitate diffusion of oxygen towards the islets (23). This same innovative device is supplied by atmospheric air and allows for easy retrieval and replacement of islets. The device has a port that is fixed on the skin through which the islets are loaded (23). Long term efficacy studies are required but this device configuration could be ideal for testing first generation insulin-producing cells obtained from stem cells. The other approach is encapsulation of islets in their own individual microcapsule. Microcapsules are spherical and suffer less from diffusion issues due to more optimal volume to surface ratios (24) (Figure 1.c). Furthermore, microcapsules display sufficient structural integrity and cell incorporation is possible via nontoxic molecules and reagents. The majority of the approaches in this direction rely on polysaccharides such as alginate as the primary material coupled with a thin polyamin coating to provide immunoprotection or to enhance mechanical stability even more (25). Biocompatibility can be enhanced by identification of alginate analogs that do not provoke strong inflammatory responses, application of anti-biofouling molecules such as polymer brushes, immunomodulating biomaterials such as zwitterions (26-28) as well as by intracapsular modifications to lower the susceptibility of cells to inflammatory stress (29). A challenge however is finding and documenting a proper relationship between surface properties and biological response in the body to better understand the impact of surface topographies (8). Overall, there is optimism about testing different device approaches in humans, but lack of an adequate source of insulin producing cells has hampered these tests. While a significant gap exist between availability and demand for cadaveric 
pancreata (30) stem cell-derived insulin-producing cells or animal derived islets could eventually bridge this gap (31).

\section{Clinical proof-of-concept}

Clinical proof of concept for the therapeutic use of encapsulated islets has been obtained. Several groups have demonstrated long-term (ranging from 70 days to 6 months) survival of micro-and macroencapsulated porcine islet transplants in nonhuman primates $(32,33)$. Moreover, some success has been reported in humans transplanted with microencapsulated porcine islets (34). Improved HbA1c levels and reduced hypoglycemic episodes were noted in these patients for more than 600 days (34). Others reported that alginate encapsulated porcine islets reduced exogenous insulin requirements using a commercial product named Diabecell囚 (35). Most recently, stem-cell-derived $\beta$ cells were transplanted into non-immunosuppressed T1D mouse models and reportedly induced normoglycemia for up to 174 days $(27,36)$. These developments have led to the point where several companies are vigorously developing encapsulated islet products and evaluating them in clinical trials (see Table 1).

\section{Expert opinion}

The science of cell encapsulation for diabetes has progressed from basic research to a point of clinically evaluating therapeutically meaningful products on a potentially wide-scale basis. Current progress in device development has created biocompatible, long-term functioning, and retrievable cellular devices for replenishable insulin-producing cell sources. Oxygen and other essential nutrient supplying technologies have been developed that can contribute to long-term function of an efficacious glucose regulating concept. Also, current developments in stem-cell technologies have raised optimism about the scalable generation of insulin producing cell sources; although some issues still remain. These include production scale up, perfecting the interface between biomaterials, immunology, and cell function, and widening the availability of the few current stem-cell sources. Last but not least, this technology allows retrieval of implanted cell-loaded devices which represents a critical safety aspect and a unique advantage of encapsulation devices. This may especially relevant when living medicines are implanted into accessible sites such as the omental pouch. Progress on some of the key parameters described 
herein may help to accelerate the translation of insuling releasing cell-laden hydrogels into medical reality.

\section{Funding}

This paper was not funded.

\section{Declaration of interest}

The authors have no relevant affiliations or financial involvement with any organization or entity with a financial interest in or financial conflict with the subject matter or materials discussed in the manuscript. This includes employment, consultancies, honoraria, stock ownership or options, expert testimony, grants or patents received or pending, or royalties.

\section{Reviewer disclosures}

Peer reviewers on this manuscript have no relevant financial or other relationships to disclose.

\section{Acknowledgements}

Authors wish to thank the Spanish Ministry of Economy, Industry and Competitiveness (SAF2016-76150-R and BFU2017-82421-P) and technical assistance from the ICTS NANBIOSIS (Drug Formulation Unit, U10) at the University of the Basque Country. We also appreciate the support from the Basque Country Government (Grupos Consolidados, No ref: IT907-16). Izeia Lukin thanks the Basque Government for the PhD grant. 


\section{References}

\section{Papers of special note have been highlighted as:}

* of interest

\section{** of considerable interest}

1. Norris JM, Johnson RK, Stene LC.Type 1 diabetes-early life origins and changing epidemiology. Lancet Diabetes Endocrinol. 2020;8(3):226-238.

2. Idf: Diabetes facts and figures [internet]. Belgium: International Diabetes Federation; 2019. Available from: https://idf.org/aboutdiabetes/what-isdiabetes/facts-figures.html

3. Centers for Disease Control and Prevention. National Diabetes Statistics Report, 2020. Atlanta, GA: Centers for Disease Control and Prevention, US Department of Health and Human Services; 2020.

${ }^{* *} 4$. Eizirik DL, Pasquali L, Cnop M.Pancreatic $\beta$-cells in type 1 and type 2 diabetes mellitus: different pathways to failure. Nat Rev Endocrinol. 2020. doi:

10.1038/s41574-020-0355-7.

A recent article reviewing the latest studies of islet morphology and human $\beta$-cell gene expression in type 1 and 2 diabetes mellitus (T1D and T2D), the identification and characterization of the role of T1D and T2D candidate genes at the $\beta$-cell level and the endoplasmic reticulum stress signaling.

5. Farina M, Alexander JF, Thekkedath U, et al. Cell encapsulation: Overcoming barriers in cell transplantation in diabetes and beyond. Adv Drug Deliv Rev. 2019;139:92-115

6. Chang TM. Semipermeable microcapsules. Science.1964;146:524-525

7. Lim F, Sun AM. Microencapsulated islets as bioartificial endocrine pancreas. Science.1980;210:908-910.

**8. Orive G, Emerich D, Khademhosseini A, et al. Engineering a Clinically Translatable Bioartificial Pancreas to Treat Type I Diabetes. Trends Biotechnol. 2018;36(4):445-456.

A complete description of the cell encapsulation technology for the development of a bioartificial pancreas including leading experts in the field. A detailed summary of the progress in biology, materials and encapsulation technology.

9. Memon B, Abdelalim EM.Stem Cell Therapy for Diabetes: Beta Cells versus Pancreatic Progenitors. Cells. 2020 Jan 23;9(2). 
10. Paolone G, Falcicchia C, Lovisari F, et al. Long-Term, Targeted Delivery of GDNF from Encapsulated Cells Is Neuroprotective and Reduces Seizures in the Pilocarpine Model of Epilepsy. J Neurosci. 2019;39(11):2144-2156.

11. Ghani MW, Ye L, Yi Z, et al. Pancreatic $\beta$-cell replacement: advances in protocols used for differentiation of pancreatic progenitors to $\beta$-like cells. Folia Histochem Cytobiol. 2019;57(3):101-115.

12. Lee J, Bayarsaikhan D, Bayarsaikhan G, et al. Recent advances in genome editing of stem cells for drug discovery and therapeutic application. Pharmacol Ther. 2020;107501.

13. Hu S, de Vos P. Polymeric Approaches to Reduce Tissue Responses Against Devices Applied for Islet-Cell Encapsulation. Front Bioeng Biotechnol. 2019;7:134. *14. Teramura Y, Iwata H. Bioartificial pancreas microencapsulation and conformal coating of islet of Langerhans. Adv Drug Deliv Rev. 2010;62(7-8):827-840.

This review addresses some relevant obstacles related with cell-laden hydrogels and overviews new techniques to overcome these issues, such as conformal coating and islet enclosure with cells.

15. Teramura Y, Oommen OP, Olerud J, et al. Microencapsulation of cells, including islets, within stable ultra-thin membranes of maleimide-conjugated PEG-lipid with multifunctional crosslinkers. Biomaterials. 2013;34(11):2683-2693.

16. Prochorov AV, Tretjak SI, Goranov VA, et al. Treatment of insulin dependent diabetes mellitus with intravascular transplantation of pancreatic islet cells without immunosuppressive therapy. Adv Med Sci. 2008;53(2):240-244.

17. Song S, Blaha C, Moses W, et al. An intravascular bioartificial pancreas device (iBAP) with silicon nanopore membranes (SNM) for islet encapsulation under convective mass transport. Lab Chip. 2017;17(10):1778-1792.

18. Hrvatin S, O'Donnell CW, Deng F, et al. Differentiated human stem cells resemble fetal, not adult, beta cells. Proc Natl Acad Sci U S A. 2014;111(8):30383043.

19. Naujok O, Burns C, Jones PM, et al. Insulin-producing surrogate beta-cells from embryonic stem cells: are we there yet? Mol Ther. 2011;19(10):1759-1768. 20. Evron Y, Colton CK, Ludwig B, et al. Long-term viability and function of transplanted islets macroencapsulated at high density are achieved by enhanced oxygen supply. Sci Rep. 2018;8(1):6508. 
21. Ludwig B, Ludwig S, Steffen A, et al. Favorable outcome of experimental islet xenotransplantation without immunosuppression in a nonhuman primate model of diabetes. Proc Natl Acad Sci U S A. 2017;114(44):11745-11750.

22. Barkai U, Weir GC, Colton CK, et al. Enhanced oxygen supply improves islet viability in a new bioartificial pancreas. Cell Transplant. 2013;22(8):1463-1476.

${ }^{* *} 23$. An D, Wang LH, Ernst AU, et al. An Atmosphere-Breathing Refillable Biphasic Device for Cell Replacement Therapy. Adv Mater. 2019;31(52):e1905135.

This study reports the design and testing of a modular transcutaneous biphasic cell delivery device that provides enhanced and unlimited oxygen supply by direct contact with the atmosphere.

24. Cao R, Avgoustiniatos E, Papas K, et al. Mathematical predictions of oxygen availability in micro- and macro-encapsulated human and porcine pancreatic islets. $J$ Biomed Mater Res B Appl Biomater. 2020;108(2):343-352.

25. Kendall WF Jr, Opara EC. Polymeric Materials for Perm-Selective Coating of Alginate Microbeads. Methods Mol Biol. 2017;1479:95-109.

26. Liu Q, Chiu A, Wang LH, et al. Zwitterionically modified alginates mitigate cellular overgrowth for cell encapsulation. Nat Commun. 2019;10(1):5262.

**27. Vegas AJ, Veiseh O, Gurtler M, et al. Long-term glycemic control using polymer-encapsulated human stem cell-derived beta cells in immune-competent mice. Nat Med. 2016;22(3):306-311.

Design and development of cell-laden hydrogels based on a new type of alginate that

induced glycemic correction without any immunosuppression until their removal at 174 days after implantation. Human C-peptide concentrations and in vivo glucose responsiveness demonstrated therapeutically relevant glycemic control. Implants retrieved after 174 days contained viable insulin-producing cells.

28. Spasojevic M, Vorenkamp J, Jansen M, et al. Synthesis and Phase Behavior of Poly(N-isopropylacrylamide)-b-Poly(L-Lysine Hydrochloride) and Poly(NIsopropylacrylamide-co-Acrylamide)-b-Poly(L-Lysine Hydrochloride). Materials (Basel). 2014;7(7):5305-5326.

29. Llacua LA, Hoek A, de Haan BJ, et al. Collagen type VI interaction improves human islet survival in immunoisolating microcapsules for treatment of diabetes. Islets. 2018;10(2):60-68. 
30. Bruni A, Gala-Lopez B, Pepper AR, et al. Islet cell transplantation for the treatment of type 1 diabetes: recent advances and future challenges. Diabetes Metab Syndr Obes.2014;7:211-223.

31. Cooper DK, Ekser B, Ramsoondar J, et al. The role of genetically engineered pigs in xenotransplantation research. J Pathol. 2016;238(2):288-299.

32. Dufrane D, Goebbels RM, Saliez A, et al. Six-month survival of microencapsulated pig islets and alginate biocompatibility in primates: proof of concept. Transplantation. 2006;81(9):1345-1353.

33. Safley SA, Kenyon NS, Berman DM, et al. Microencapsulated adult porcine islets transplanted intraperitoneally in streptozotocin-diabetic non-human primates. Xenotransplantation. 2018;25(6):e12450.

34. Matsumoto S, Abalovich A, Wechsler C, et al. Clinical Benefit of Islet Xenotransplantation for the Treatment of Type 1 Diabetes. EBioMedicine. 2016;12:255-262.

35. Hillberg AL, Oudshoorn M, Lam JB, et al. Encapsulation of porcine pancreatic islets within an immunoprotective capsule comprising methacrylated glycol chitosan and alginate. J Biomed Mater Res B Appl Biomater. 2015;103(3):503-518.

36. Pagliuca FW, Millman JR, Gurtler M, et al. Generation of functional human pancreatic beta cells in vitro. Cell. 2014;159(2):428-439. 


\section{Figures}

Figure 1: Schematic illustration of the various islet delivery schemes on the market today. (A) Islet cells are implanted within a biomaterial device in the vicinity of a vascular network. (B) Other schemes capitalize upon more ingenious devices that can deliver oxygen to the entrapped cells from outside the body. (C) Hydrogel microencapsulation provide a more biomimetic approach, wherein islet cells are injected into the patient within a native-like matrix that protects them from harm, while providing them with optimal growth and functioning conditions. 


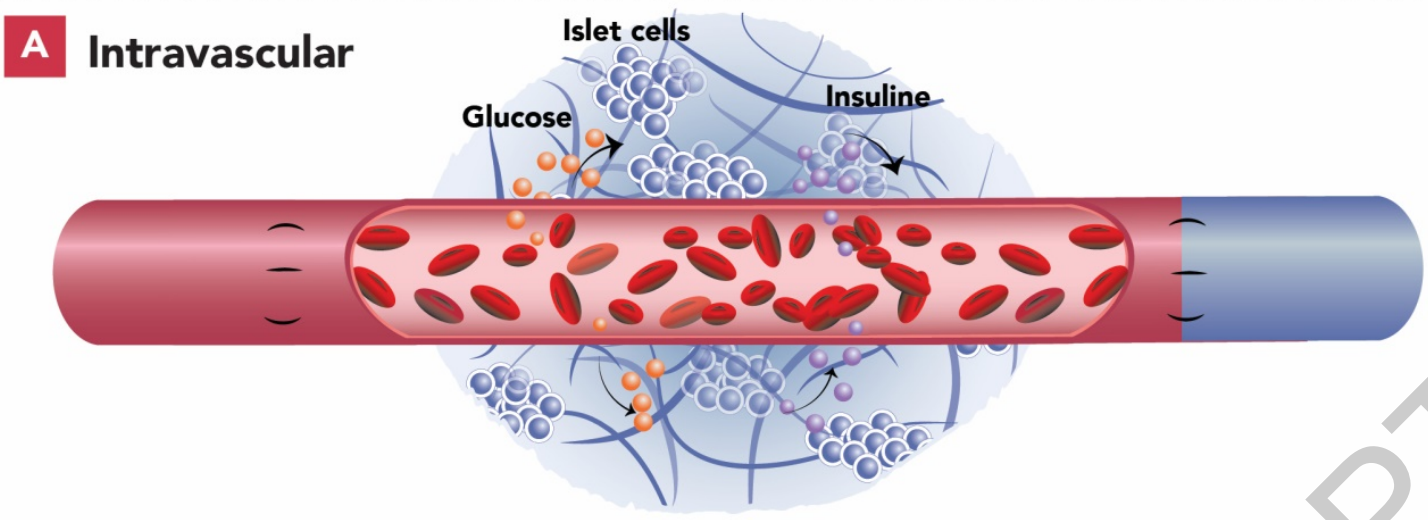

B Extravascular

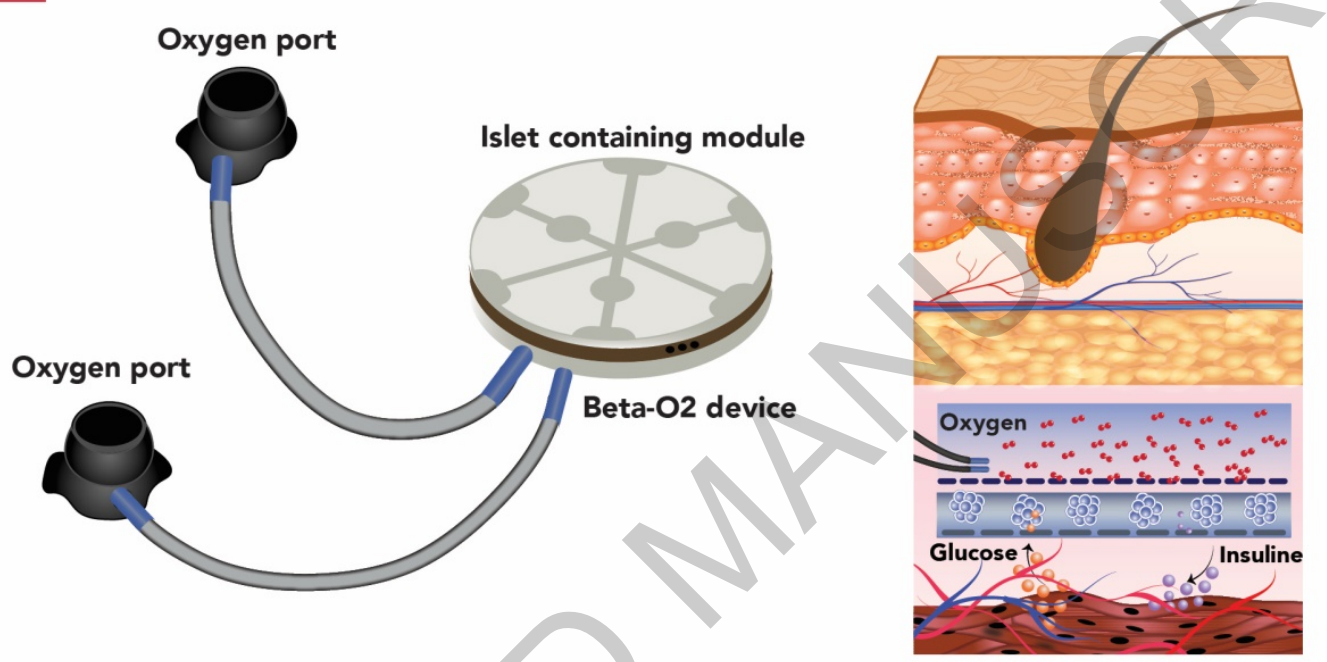

C Islet microcapsulation

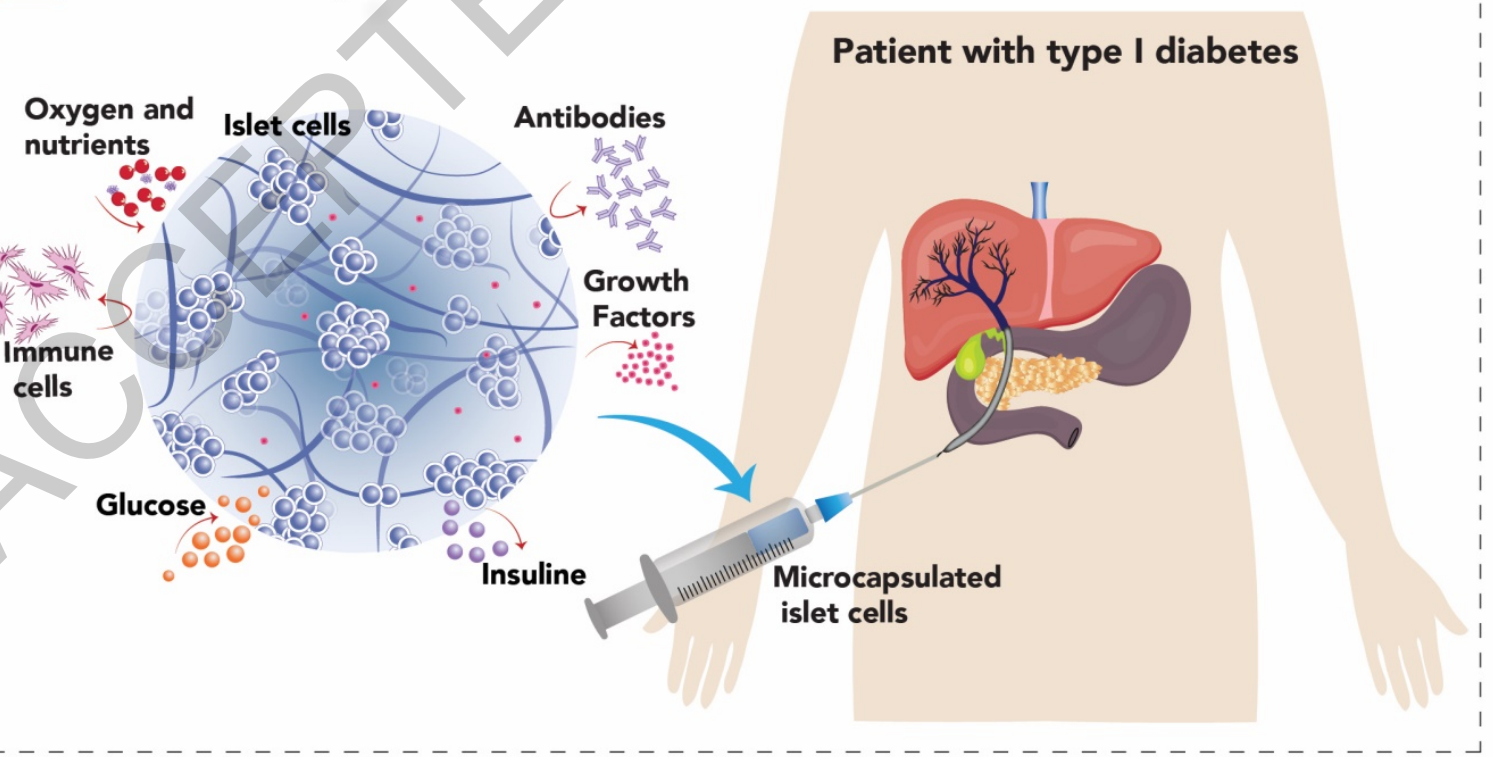

Table 1. Current clinical trials summary. Developed devices for diabetes application. 


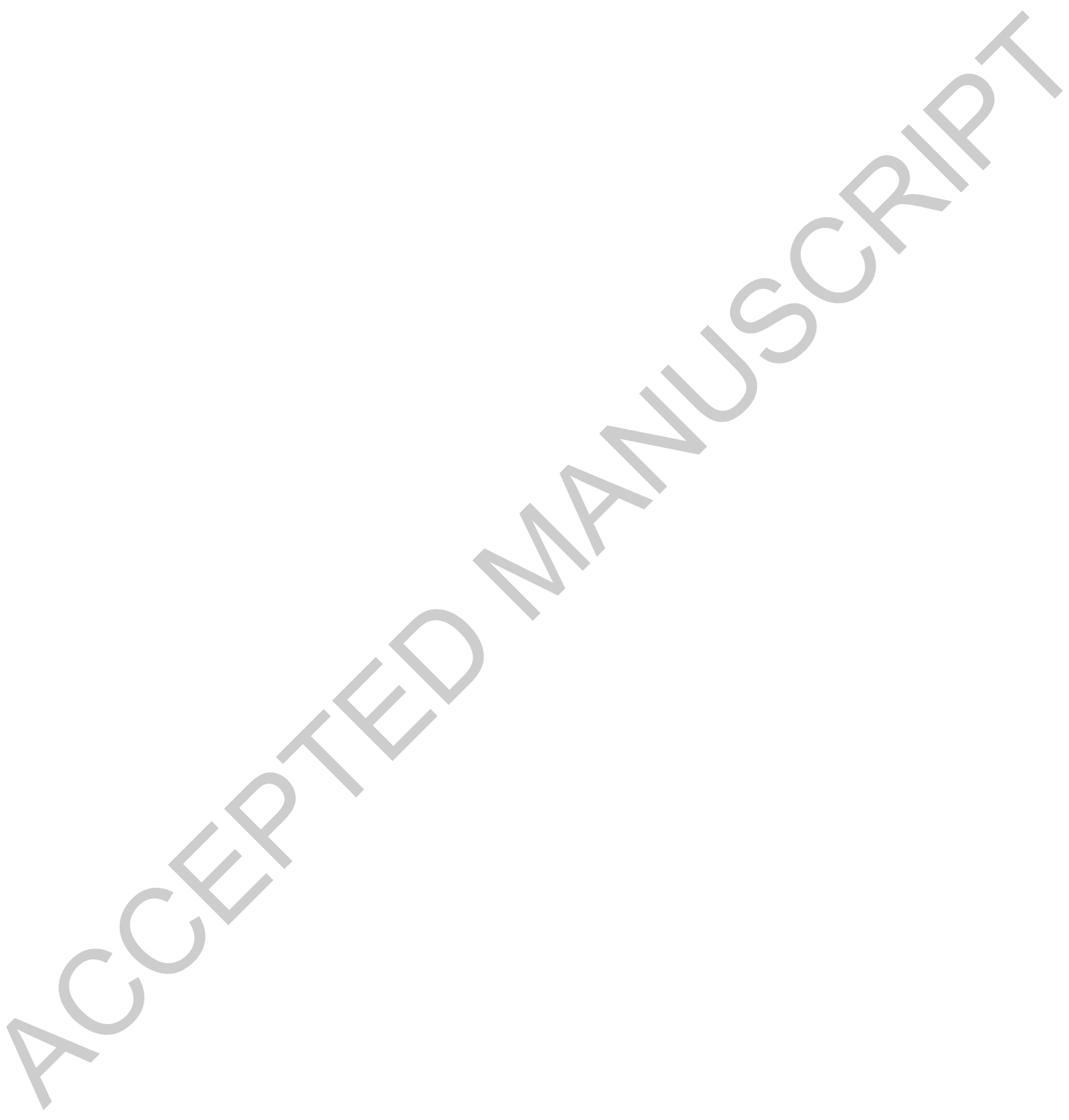


Encaptra ${ }^{\circledR}$ drug delivery system allows pancreatic precursor cells to deliver, differentiate and mature after surgical implantation

A system designed to allow blood vessels to enter the device and directly interact with the implanted pancreatic precursos cells.

\begin{tabular}{|c|c|}
\hline $\begin{array}{l}\text { G- } \\
\text { capsulated } \\
\text { et Allografts }\end{array}$ & Encapsulated islets \\
\hline ABECELL ${ }^{\circledR}$ & Encapsulated pig \\
\hline
\end{tabular}

ne-Year Follow-up Safety Study in Subjects Previously Implanted With VC$01^{\text {TM }}$.NCT02939118

A Safety, Tolerability, and Efficacy Study of VC-01 ${ }^{\mathrm{TM}}$ Combination Product in Subjects With Type I Diabetes Mellitus.NCT02239354

A Safety, Tolerability, and Efficacy Study of VC-02 ${ }^{\mathrm{TM}}$ Combination Product in Subjects With Type 1 Diabetes Mellitus and Hypoglycemia Unawareness. NCT03163511 A Safety and Tolerability Study of VC-02 ${ }^{\mathrm{TM}}$ Combination Product in Subjects With Type Diabetes Mellitus. NCT03162926

Safety and Efficacy of PEG-Encapsulated Islet Allografts Implanted in Type I Diabetic Recipients. NCT00260234

Open-label Investigation of the Safety and

An implantable medical device which provides a vascularized environment for therapeutic cells

A device that allows encapsulated cells to be properly oxygenated. Effectiveness of DIABECELL ${ }^{\circledR}$ in Patients With Type 1 Diabetes Mellitus.NCT01739829

A Safety, Tolerability and Efficacy Study of Sernova's Cell Pouch ${ }^{\text {TM }}$ for Clinical Islet -Cohort study -200 participants

2016-2021

-Phase 1/2

-69 participants

2014-2021

-Cohort study

-75 participants

-Phase 1/2

-3 participants

-Phase 1/ 2

-12 participants Transplantation.NCT03513939

An Open Label, Pilot Investigation, to Assess the Safety and Efficacy of Transplantation of Macro-encapsulated Human Islets Within the Bioartificial Pancreas Beta-Air in Patients -Phase 2

-8 participants

2011-2014

-Phase $1 / 2$

-7 participants (July

2019-2022 2019) With Type 1 Diabetes Mellitus.NCT02064309

-Phase 1/2

-4 participants
2017-2018

2005-2014

Ter 